\title{
Music as A Weapon on Asymmetric War between FWPC (Free West Papua Campaign) Against Indonesia
}

\author{
M K Jahamou' ${ }^{1}$, M Wiswayana ${ }^{2}$ \\ ${ }^{1}$ Airlangga University, Surabaya, ${ }^{2}$ Brawijaya University, Malang \\ 1'madeline.kisariani.jahamou-2019@fisip.unair.ac.id, ${ }^{2}$ wishnu.mahendra@ub.ac.id
}

\begin{abstract}
This study aimed to explained music on asymmetric war between FWPC and Indonesia as a weapon of the FWPC to attacked Indonesia. The method of this study was the propaganda techniques with the object of the study in terms of FWPC music. The results of this study indicate that music is a new weapon that has propaganda techniques in the asymmetric war between FWPC and Indonesia. In political View, the asymmetric war between FWPC and Indonesia was a struggle which is conducted by a weak actor (FWPC) to fight against strong actor (Indonesia) to achieve their purpose of their interests which is to get Freedom from Indonesia. And to achieve their purpose or to winning this asymmetric war they are using music as one of their weapons. There are 2 music's tittle which FWPC using, it is Sorong Samarai and All Nations. The values which FWPC believes and implied on the lyrics and the video clip depict that the music is one of the weapons on asymmetric war that used by FWPC to against Indonesia.
\end{abstract}

Keywords: Music as A Weapon, Asymmetric War, Free West Papua Campaign, Indonesia

\section{INTRODUCTION}

After Indonesian independence from Japan in 1945, the Netherlands continued to try to dominate Indonesia or the Dutch Hindi by carrying out Military Aggression I in 1947 which ended with the Renville agreement and Military Aggression II in 1948 which ended with the Linggarjati agreement in the Round Table conference between the Republic of Indonesia and the Netherlands held in The Hague, Netherlands [1]. In the Linggarjati agreement, the Dutch recognized the Republic of Indonesia, but only in Java, Madura, and Sumatra, as one of the states of the United States federal state, which in turn also became part of the Indonesia-Netherlands Union, with the Netherlands as the head of the Union. The exclusion of Papua or Irian Jaya as Indonesia's sovereign territory recognized by the Dutch caused problems in the future [2]. On May 1, 1963, according to the New York Agreement, Indonesia took over the territory of Papua [3].

After Sukarno was removed by the Suharto military regime, Indonesia succeeded in cooperating with West Papua to integrate with Indonesia through what 
was called PEPERA [4]. After transferring power from president Sukarno to president Suharto, the struggle for Papua was increasingly manipulated by Indonesian rule. This is because of the certainty of the land of Papua (Irian Barat) After transferring power from president Sukarno to president Suharto, the struggle for Papua was increasingly manipulated by Indonesian rule. This is because the certainty of the land of Papua (West Irian) is in the grip of the sovereignty of the Suharto regime, so it is designed and carried out manipulation of free choice in the land of Papua [4]. After annexing Papua, the Indonesian government began terrorizing the people of Papua who did not believe in the results of PEPERA. Indonesia accused that for anyone who doubted or did not believe in the results of the "free choice" and carried out a resistance movement, they were separatists [4]. In fact, the existence of groups that are considered separatists is used as an excuse for the Indonesian government to evict residents of their land for the benefit of Freeport and then forcibly evacuate them to improper settlements, burn villages, torture, and extra judicial killings [5]. Until finally in Papua, democratic actions by mobilizing the masses towards local centers of power began to spread in various cities by involving civilian political actors such as churches, students, youth, indigenous organizations and NGOs. Democratic demands for past human rights crimes, rejecting militarism and denying Freeport's presence in Papua were voiced by students, intellectuals, NGO activists, and religious figures [6].

Since Indonesia took over West Papua from the Netherlands, there have been many atrocities and human rights violations committed against tribes in Papua. The many atrocities and human rights violations that occurred eventually led to many local organizations and groups in Papua and abroad to defend and voice what happened in Papua [7]. Formed in 2004 by Benny Wenda in Oxford, England, the FWPC or the Free West Papua Campaign is an organization that conveys public campaigns for the people of West Papua to gain freedom to choose their own destiny through a fair and transparent referendum [8]. The history of the formation of the FWPC begins with the life story of Benny Wenda, the founder of the FWPC who will be the author to review further in the next sub-chapter. In 2002, two years before the formation of Free West Papua Campaign, Benny Wenda was arrested in Jayapura on charges of attacking a police station that caused him to receive a sentence of 25 years in prison [9]. After successfully escaping to Papua New Guinea, Benny Wenda was granted asylum rights from the United Kingdom in the same year based on Indonesian persecution carried out on him for his political reasons [9].

Until 2004, Benny Wenda formed Free West Papua Campaign in Oxford, England [8]. Benny Wenda himself has made many trips as a form of his campaign against what is happening to the people of West Papua through the FWPC. In collaboration with politicians from various parties and also with other NGOs and campaign groups nationally and internationally on the basis of the objectives to be achieved by the FWPC [10], to make the FWPC has spread in 15 countries such as Australia, Canada, Fiji, Finland, Germany, Indonesia, Mexico, The Netherlands, New Zealand, Papua New Guinea, Poland, South Africa, Spain, the United Kingdom, and the United States [11]. Apart from the collaboration, FWPC itself has official offices in Oxford, The Hague, Port Moresby and Perth [11]. The formation, development and 
distribution of FWPC from this historical view is evidence that the asymmetrical war between FWPC and Indonesia has also developed. The Asymmetrical war itself means a new form of warfare, on in which conventional nations-state pitted against groups and organizations that are no themselves nation-state [12]. Carter continue on his argument said, the claim that new form of warfare has come into existence is not a merely empirical claim about the advent of new technologies, tactics, or strategies. This shift may be due in part to advent of new instruments and techniques of war [12]. Based on that argument, there is new instruments and techniques of asymmetric war between FWPC and Indonesia. Which I argue that music of FWPC is one of them.

\section{RESEARCH METHOD}

This paper used propaganda techniques analysis, a research approach that focuses on a focus description and explanation about a research object. The object of this study is the music which used by FWP. There are 2 music's tittle, Sorong Samarai and All Nations. The data were obtained by literature research to focus on Sorong Samarai's song and All Nations's song based on their music, lyric, and video clip. A literature research is one of the fastest and least expensive means to discover hypothesis and provide information about the subject we're studying [13]. The data were, then, analyzed with propaganda's techniques. This model consisted of nine stages, which is, name calling, glittering generalities, transfer, testimonial, flain folks, bandwagon, card stacking, emotional stereotype, and retorika.

\section{RESULTS AND DISCUSSION}

Songs and sounds are more powerful weapons in this armory because of the music works directly on our emotions [14]. This part will explain the analysis result of propaganda techniques from FWPC's music weapon. From the lists of songs, there are 2 songs about their support to FWPC. These songs are Sorong Samaria by Airileke and Twin Tribe and All Nations by Blue King Brown. These songs use FWPC symbols and propaganda techniques on the lyric, music, and video clip, which are used as weapon for attacking Indonesia occupation in West Papua. And that weapon not directed directly at Indonesia but directed at the international community through

social media platform so Indonesian government will react to the international community.

The first song's tittle is Sorong Samarai by Airileke and Twin Tribe. Sorong Samarai (the title song) or S2S is a place name that extends from PNG and West Papua and is expressed in song form to express solidarity and to state the relationship between Sorong (a small town in Papua Barat) and Samarai (a small town in the lower end of the PNG country). Airileke is a Melanesian artist who lives in Melbourne and was nominated for ARIA through the album Weapon of Choice in 2012 saying that we wanted to positively present the beauty of West Papua and PNG and the strength of its culture and people so the wider community connects emotionally to the situation and begins to take a stronger interest [15]. This means that Airileke dan Twin Tribe and 
the team want to show the beauty of West Papua and PNG as well as the power of culture and people to connect emotionally to the larger community in a situation and begin to take on the interests that stronger.

I argue that there are five of propaganda techniques on this song. First technique is Glittering Generalities (a propaganda technique that uses bombastic words so people unconsciously follow it) [16]. This technique i found on Sorong Samarai's lyrics which said "rise up freedom fighter, rise up and takes your stands again, satu orang satu Tifa (one man, one Tifa), suara nenek moyang kita, and Papua tanah kami. I argue that those words are Glittering technique which is work to explain what those songs about. Like one man, one Tifa, Tifa is a traditional instrument which used to conduct a war on tribe war. It means that this song tells the audiences that west Papuan are preparing themselves to a war.

Second technique is Transfer (a propaganda technique that is done by way of diversion to other objects) [16]. This technique I found on Sorong Samarai's video clip which more focusing on the culture, the view of Papua's island and traditional instrument. My argument is Airileke and Twin Tribe are trying to deliver their song's message by focusing on the culture, island, and traditional instrument beside the history of the conflict or the impact of the war. This technique can also find when the instrument is more dominant than the lyric itself. Third technique is Card Stacking (a propaganda technique that used to convey facts to convince others) [16]. Card Stacking on Sorong Samarai song can found on an opening text on Sorong Samarai's video clip. It said "west Papua is a country in waiting, fighting for freedom from a brutal Indonesia occupation, separated only by a colonial border." My argument for those words is either Airilike or Twin Tribe want to deliver an untested statement to show that it is a fact that Indonesia are doing occupation in West Papua.

Fourth techniques is Emotional Stereotype (a propaganda technique used to foster emotional suspicion) [16]. This technique I found on text opening which said "fighting for freedom from a brutal Indonesia occupation". Those words will lead the audience to have bad or angry emotion to Indonesia. Even more it will lead the audience to believe those words without check or studying about the history. It means this text opening are trying to influence the audience at the beginning they listened to this song. Fifth techniques is Retorika (a propaganda technique that is used by choosing words that can attract someone so that the person can obey the propagandist will) [16]. This technique on Sorong Samarai song can be found on the first lyric which said "light up the fire, let the fire burn, rise up freedom fighter, rise up and takes your stands again". Those lyrics mean the singers are inviting the audiences to fight again which prefer to fighting against Indonesia to get the freedom. Other lyrics that represent this technique are "Melanesian you may rise up again, sing to claim the land and sea, get you up your own choice, come back again". These lyrics trying too explain that people (West Papuan) now had opportunity to rise again and fight because there is a dawn when the new day comes. It means those lyrics are giving hope to people who fight for west Papuan.

The second song's tittle is All Nations by Blue King Brown. This song was written and sung by Nattali Rize whose incorporated in the Blue King Brown. Nattali 
Rize is a singer, guitarist, and songwriter known for his pop-rock music which is influenced by reggae music and political thought [17]. Nattali Rize is also known throughout the world through his commitment to use his voice and music for the global struggle towards the realization of total freedom and movement for truth and justice towards the exploitation of the system of people and our planet [18]. In All Nations' song, Nattali Rize are trying to deliver her politics and support's message through the lyrics and the music video clip.

I argue that there are four propaganda techniques on this song. First, Name Calling (a propaganda techniques that used to vilify others by casting funny or cynical titles) [16]. This technique can be found on the lyrics which said "watch out for cops, they come around then violence escalating, beating on our women and children, hating like they really mean it." The "they" term on this song are representing cops from Indonesia because on this video clip is refer to conflict that held between FWPC and Indonesia (based on the flag symbols and the Papua Merdeka word that appear on the video clip). Second, Transfer which can found on the lyrics that said "this world depends upon it, hear all the people call it, and when the future is calling you, you can't ignore it. Transfer techniques refer to the hope that will appear if people are together to sounding the West Papuan conflict which transferring the fact about what really happened there.

Third, Emotional Stereotype that can be found on lyrics that said "Situation here is getting worse everyday, care about tomorrow?" this lyric can be an accusation which can make audience had emotional feeling to the West Papuan and will hate the Indonesia. Fourth, Retorika that can be found on lyrics that said "Dreaming of a day there is justice under this sun looking at this movement, big up them, freedom fighters giving all their living, keep us thinking now we will not forget them, all nations, calling all nations." This lyric means that there are hope if the freedom fighters are fighting on this war and all nations are being called to hear about this conflict and fixed it together.

\section{CONCLUSIONS}

Music is not just an art that can be enjoyed by many people. Furthermore, music can be used to spread political messages and can be used as weapons because the nature of music is directly received by the ear and processed by the mind which will change the way of viewing and behaving in certain circumstances. In the case of an asymmetric war between FWPC and Indonesia, FWPC used music as a weapon to fight Indonesia. The expectation is that the presence of music that has propaganda techniques in it can influence the audience to side with FWPC.

\section{REFERENCES}

[1] A. Iqbal, Perang-perang paling berpengaruh di Dunia. Yogyakarta: Galangpress, 2010.

[2] G. Oostindie, Serdadu Belanda di Indonesia 1945-1950 Kesaksian Perang 
Pada sisi Sejarah yang Salah. Jakarta: Obor Indonesia, 2016.

[3] Anonymus, "West Papua." [Online]. Available: http://unpo.org/members/7843.

[4] Paharizal; dan Ismantoro Dwi Yuwono, Freeport Fakta-fakta yang Disembunyikan. Yogyakarta: Narasi, 2016.

[5] A. Vltechek, Indonesia: Untaian Ketakutan di Nusantara. Jakarta: Badak Merah, 2014.

[6] S. R. R. dan C. Pamungkas, Updating Papua Road Map: Proses Perdamaian, Politik Kaum Muda, dan Diaspora Papua. Jakarta: Pustaka Obor Indonesia, 2017.

[7] J. Titifanue, J. Tarai, R. Kant, and G. Finau, "From Social Networking to Activism: The Role of Social Media in the Free West Papua Campaign," Pac. Stud., vol. 39, no. 3, pp. 255-281, 2016.

[8] "About the Campaign - Free West Papua." [Online]. Available: https://eu1.proxysite.com/process.php?d=lz\%2BZ5XoKzyyJC3QC43IzXVT UeBuVh\%2F1f74RBVEXqqjLwyRbdNd714GBvF\%2BMxZmfpCEo\%3D $\& \mathrm{~b}=1$. [Accessed: 18-Nov-2019].

[9] F. T. International, "Benny Wenda." [Online]. Available: https://www.fairtrials.or/documents/Benny_Wenda_Spotlight.pdf. [Accessed: 04-Dec-2017].

[10] Anonymus, "About The Campaign." [Online]. Available: https://www.freewestpapua.org/info/about-the-campaign/. [Accessed: 14Nov-2019].

[11] Anonymus, "Info." [Online]. Available: https://www.freewestpapua.org/info/west-papua-campaign-groups/.

[12] J. A. Carter, "Just or New War Theory: Non-State Actors in Asymmetric Conflicts," Philos. Contemp. World, vol. 16, no. 2, p. 11, 2009.

[13] M. Yousaf, "Explanatory Research Definition, Explanatory Research Types, Comparison, Advantages, Disadvantages Explanatory Research Design." [Online]. Available: https://scholarshipfellow.com/explanatory-researchdefinition-types-comparison-advantages-disadvantages/.

[14] J. Street, Fight the Power: The POlitics of Music and The Music of Politics. Oxford: Backwell Publishing, 2003.

[15] Anonymus, "Music." [Online]. Available: http://www.rizeofthemorningstar.com/\#3.

[16] H. Cangara, Komunikasi Politik Konsep, Teori, dan Strategi. Jakarta: Rajagrafindo Persada, 2011.

[17] M. Collar, "Artist Biography." [Online]. Available: https://www.allmusic.com/artist/nattali-rize-mn0003561271/biography.

[18] Anonymus, "Nattali Rize." [Online]. Available: https://www.reggaeville.com/artist-details/nattali-rize/about/. 